\title{
SPRAY RETENTION ON COFFEE LEAVES ASSOCIATED WITH TYPE AND CONCENTRATION OF ADJUVANTS
}

\author{
José E. da C. R. Cação ${ }^{1}$, Bruno R. de A. Moreira ${ }^{1}$, Carlos G. Raetano ${ }^{2}$, Fernando K. Carvalho ${ }^{3}$, \\ Evandro P. Prado ${ }^{*}$
}

${ }^{1 *}$ Corresponding author. Universidade Estadual Paulista - UNESP/ Dracena - SP, Brasil.
E-mail: evandro.prado@unesp.br | ORCID ID: https://orcid.org/0000-0001-7616-0471

\section{KEYWORDS}

Surfactant; run-off; spreading area; pesticide application technology.

\begin{abstract}
Agricultural spray adjuvants (ASA) are widely used in pesticide applications to enhance the performance of pesticides. The aim of this research was to investigate the effects of ASA on static surface tension (SST) and foliar spray retention on coffee leaves. The SST of ASA at different concentrations was determined by the drop weight method. Spray retention on adaxial and abaxial coffee leaf surfaces was performed using a micro-sprayer at solution concentrations of $0,0.01,0.1,0.5$, and $1.0 \% \mathrm{v} \mathrm{v}^{-1}$. The ASA assessed were: polyether-polymethylsiloxane-copolymer (PPC); Nonylphenol ethoxylate; nonyl polyethylene glycol ether; mineral oil; nonylphenoxy polyethoxy ethanol; carboxyl copolymer of styrene and butadiene; primary aliphatic oxyalkylated alcohol plus carboxyl copolymer of styrene and butadiene; and soyal phospholipids and propionic acid. All ASA reduced the SST of the aqueous solutions. PPC provided the best performance in decreasing SST, reaching values below $20 \mathrm{mN} \mathrm{m}^{-1}$ at a concentration of $0.05 \% \mathrm{v} \mathrm{v}^{-1}$. Spray retention on leaves was influenced by adjuvant type as well as concentration. A very strong positive correlation between SST and spray retention on coffee leaves was observed. Decreasing the SST of the solution provided a reduction of spray retention when spraying was performed until run-off point.
\end{abstract}

\section{INTRODUCTION}

The mitigation of risk of pesticide application is currently a priority for achieving sustainable agriculture. Pesticide losses by run-off, leaching, evaporation, and drift during spray application may increase environmental pollution and result in adverse effects to living organisms (Mahmood et al., 2016).

To ensure the efficiency of chemical treatments, the droplets containing the pesticide active ingredient must stick on the target surface regardless of the pesticide applied (systemic or contact). Agricultural spray adjuvants (ASA) can influence the spray deposition and retention of pesticide droplets on the plant surface. When a droplet impacts a leaf surface, three outcomes are possible: adhesion, bounce, or shatter (Zwertvaegher et al., 2014).

There are many factors that contribute to the performance of pesticide applications. Droplet size, droplet velocity, leaf surface structure (waxy or hairy), the chemical composition of the spray solution, and meteorological conditions (air temperature, wind velocity, and relative humidity) may greatly influence the coverage area and consequently control of weeds, diseases, mites, and insects. The proper ASA used in the pesticide tank mix may contribute to improving the performance of the application (Alves \& Cunha, 2014; Sasaki et al., 2015).

Static surface tension (SST) constitutes one of the most important properties of the spray tank mix, being able to influence the biological activity of the pesticides. Reduction of SST by adjuvants may improve the adhesion, spreading, wetting, and penetrating effects of the pesticides, as well increase translocation of the active ingredients into the plant tissues (Gimenes et al., 2013; Gitsopoulos et al., 2014; Lin et al., 2016; Zhu et al., 2018). However, attention in some circumstances is necessary, especially regarding the run-off of spray droplets that reach the leaves (Costa et al., 2015; Prado et al., 2016).

Brazil is the largest world producer and exporter of coffee (Pinto et al., 2014). Among the crops produced in

\footnotetext{
${ }^{1}$ Universidade Estadual Paulista - UNESP/ Dracena - SP, Brasil.

${ }^{2}$ Universidade Estadual Paulista - UNESP/ Botucatu - SP, Brasil.

${ }^{3}$ AgroEfetiva/ Botucatu - SP, Brasil

Received in: 10-22-2018

Accepted in: 8-20-2019
} 
Brazil, where pesticides and ASA are frequently used, coffee is of great importance. Pesticides on coffee plants are frequently applied using a higher spray volume specifically to control insects such as mealybugs and mites that are inside bark crevices (Dorr et al., 2014; Dorr et al., 2016; Santinato et al., 2017). To reach these pests, many coffee producers increase the spray volume to provide better penetration and deposition inside the coffee canopy, which may lead to excessive losses by run-off (Decaro Junior et al., 2014; Decaro Junior et al., 2015). In addition to the higher spray volume application, a tank mix adjuvant that reduces the SST of the spray solution can negatively influence the amount of deposits retained on the leaves of the coffee plants (Silva et al., 2008).

Although a wide variety of ASA have been shown to increase spray deposition on foliage, there is little quantitative information regarding the effectiveness of different classes of adjuvant used as retention enhancers, especially when applying high spray volumes, usually for crops such as coffee. Due the frequent use of ASA, understanding the effects on spray retention using excessive spray volume may be valuable to avoid losses and increase the performance of pesticides. Thus, the objective of the present research was to evaluate the SST of solutions containing ASA, as well as the foliar retention of these spray solutions applied on coffee leaves until runoff point.

\section{MATERIAL AND METHODS}

\section{Static surface tension determination}

SST assessments were performed in the laboratory of Pesticide Application at the College of Technology and Agricultural Science UNESP - Campus of Dracena. The solutions were tested at 15 concentration levels for each one of seven adjuvants $(0,0.001,0.0025,0.005,0.0075$, $0.01,0.025,0.05,0.075,0.1,0.25,0.5,0.75,1.0$, and $2.0 \%$ $\left.\mathrm{v} \mathrm{v}^{-1}\right)$. Details of the adjuvants' composition are summarized in Table 1.

TABLE 1. Agricultural adjuvants' description assessed in the experiments of surface tension and spray retention on coffee leaves.

\begin{tabular}{|c|c|c|c|}
\hline $\begin{array}{c}\text { Commercial } \\
\text { name }\end{array}$ & Use and composition & $\begin{array}{l}\text { Label dose } \\
\mathrm{V} \mathrm{v}^{-1}(\%)\end{array}$ & Supplier \\
\hline Break Thru & $\begin{array}{c}\text { Super-spreader penetrant surfactant }-1000 \mathrm{~g} \mathrm{~L}^{-1} \text { polyether-polymethylsiloxane-copolymer } \\
\text { (PPC) }\end{array}$ & Until 0.1 & $\begin{array}{c}\text { Evonic } \\
\text { Degussa }\end{array}$ \\
\hline Adesil & $\begin{array}{c}\text { Spreader sticker surfactant }-250 \mathrm{~g} \mathrm{~L}^{-1} \text { nonylphenol } \\
\text { ethoxylate (NE) }\end{array}$ & 0.03 & Nufarm \\
\hline In-Tec & Spreader sticker - $124.4 \mathrm{~g} \mathrm{~L}^{-1}$ nonyl polyethylene glycol ether (NPGE) & 0.05 & Inquima \\
\hline Nimbus & Adjuvant $-428 \mathrm{~g} \mathrm{~L}^{-1}$ mineral oil (MO) & 0.5 & Syngenta \\
\hline Agral & Spreader sticker surfactant - $200 \mathrm{~g} \mathrm{~L}^{-1}$ nonylphenoxy polyethoxy ethanol (NPE) & 0.03 & Syngenta \\
\hline Tactic & Spreader sticker - $640 \mathrm{~g} \mathrm{~L}^{-1}$ carboxyl copolymer of styrene and butadiene (CCSB) & $0.05-0.25$ & $\begin{array}{l}\text { De Sangosse } \\
\text { Agroquímica }\end{array}$ \\
\hline Grip & $\begin{array}{c}\text { Spreader sticker }-100 \mathrm{~g} \mathrm{~L}^{-1} \text { primary aliphatic oxyalkylated alcohol }+450 \mathrm{~g} \mathrm{~L}^{-1} \text { carboxyl } \\
\text { copolymer of styrene and butadiene (PAOA) }\end{array}$ & $0.125-0.25$ & $\begin{array}{l}\text { De Sangosse } \\
\text { Agroquímica }\end{array}$ \\
\hline Li-700 & $\begin{array}{l}\text { Acidifying and penetrating surfactant }-350 \mathrm{~g} \mathrm{~L}^{-1} \text { soyal } \\
\text { phospholipids and } 350 \mathrm{~g} \mathrm{~L}^{-1} \text { propionic acid (SPPA) }\end{array}$ & 0.5 & $\begin{array}{l}\text { De Sangosse } \\
\text { Agroquímica }\end{array}$ \\
\hline
\end{tabular}

The SST of the aqueous solution was determined by the gravimetric method quantifying the weight of the droplets formed at the tip of a glass capillary burette (50 $\mathrm{mL}$ capacity) placed in a vertical direction (Prado et al., 2016). The free droplets detached at the tip of the glass, falling into a $25 \mathrm{~mL}$ beaker containing $30 \mathrm{~mL}$ of vegetable oil to avoid solution evaporation. The beaker was located within the analytical precision balance with $0.0001 \mathrm{~g}$ accuracy (Marte, model ATY 224, Santa Rita do Sapucai, $\mathrm{MG}, \mathrm{BR}$ ) and the tip of the glass burette was kept $10 \mathrm{~cm}$ above the beaker.

The burette was adjusted to form droplets at the time between 15 to 20 seconds and the liquid column was kept at $25 \mathrm{~mL}$ of the graduation scale. The test was carried out at a temperature of $25 \pm 1{ }^{\circ} \mathrm{C}$ and relative air humidity of $60 \pm$ $10 \%$. Fifteen droplets were measured per treatment and each droplet considered a repetition (Carvalho et al., 2017). All adjuvant solutions were prepared with deionized water.

Since the weight concentrations of surfactant were low, both the liquid density and viscosity of the surfactant solution were considered similar to the deionized water. The average droplet weight data were converted into surface tension according to [eq. (1)], described by Behring et al. (2004):

$$
\gamma=\frac{m g}{2 \pi r f}
$$

Where:

$$
\begin{aligned}
& \gamma=\text { surface tension }\left(\mathrm{mN} \mathrm{m}^{-1}\right) ; \\
& m=\text { average droplet mass }(\mathrm{g}) ; \\
& g=\text { gravitational acceleration }\left(980 \mathrm{~cm} \mathrm{~s}^{-2}\right) ; \\
& \pi=\text { pi }(3.1416) ; \\
& r=\text { internal radius of the burette tip where the } \\
& \text { droplet is formed }(0.2037 \mathrm{~mm}), \text { and } \\
& f=\text { correction factor }(0.6461) .
\end{aligned}
$$

\section{Spray retention determination}

Spray applications on coffee leaves were conducted using solutions containing the same adjuvants described previously (Table 1). The adaxial and abaxial surfaces of the coffee leaves were sprayed separately with adjuvant aqueous solutions at concentrations of $0,0.01,0.1,0.5$, and $1.0 \% \mathrm{~V} \mathrm{v}^{-1}$ with five replications (each leaf side was considered one repetition). These concentrations were chosen in order to have a good representation of the 
adjuvant label doses tested in this research. The coffee leaves were collected from six year old plants of Coffee Arabica cultivar Mundo Novo, grown under noncontrolled environmental conditions at a spacing of $0.8 \times$ $4.0 \mathrm{~m}$, located in the College of Technology and Agricultural Science. Plants had uniform architecture with $2.0 \mathrm{~m}$ in height and $1.0 \mathrm{~m}$ in diameter of the canopy closer to the ground. Soil at this location is classified as Distrofic Ultisol (Santos et al., 2018). The climate, according to Köeppen's classification, is Aw (tropical savanna, with a dry winter and hot, rainy summer). Coffee branches were removed from the trees and immediately carried to the laboratory. The base of the removed branches containing the leaves were kept into a $1 \mathrm{~L}$ pot filled with water before being sprayed, to avoid leaf dehydration. Mature coffee leaves were removed from the branches and had their weights determined by analytical precision balance (Marten, model AY 220, São Paulo, SP, BR).

Afterwards, the leaves were placed in a vertical position (holding the petiole leaves by hand) and the adjuvant aqueous solution was sprayed by a portable micro-sprayer which consisted of a dual action gravity feed airbrush (Sagyma SW - 775) with a $0.3 \mathrm{~mm}$ tip, pressured by an airbrush compressor (Sagyma ASW-18) at $151.8 \mathrm{kPa}$, spraying very fine droplets (volumetric median diameter of $32 \mu \mathrm{m}$ ) determined by a VisiSize Portable P15 (Oxford Lasers, Imaging Division, Oxford, U.K.), according to Carvalho et al. (2017).

The spraying was performed on one side of the leaves at a distance from the airbrush of $0.3 \mathrm{~m}$ until the run-off point was reached at a temperature of $23 \pm 2{ }^{\circ} \mathrm{C}$ and $65 \pm 10 \%$ relative air humidity. The spraying until runoff point was performed to simulate a high spray volume application. After spraying, the leaves were again weighed and the spray solution retained was measured by weight difference. The area of each leaf was measured according to methodology described by Silva et al. (2008).

The width and length of the leaves were measured by a transparent graduated ruler. The first measurement being obtained in the central region of the leaves, with the ruler positioned transversely to the central vein and the second measured with the ruler arranged parallel to the central vein, proceeding to the reading of the leaf apex to the base of insertion of the petiole (Silva et al., 2008). The leaf area was calculated using [eq. (2)]:

$$
A=c * l * k
$$

Where:

$$
\begin{aligned}
& A=\text { foliar area }\left(\mathrm{m}^{2}\right) ; \\
& c=\text { leaf length }(\mathrm{m}) ; \\
& l=\text { leaf width }(\mathrm{m}), \text { and } \\
& k=\text { correction factor }(0.663) \text { (Silva et al., 2008). The } \\
& \text { weight value was divided by the foliar area of each } \\
& \text { leaf and the retention results expressed in } \mathrm{mL} \mathrm{m}^{-2} .
\end{aligned}
$$

\section{Statistical analysis}

Statistical analysis of SST dates of each adjuvant was performed using the Software $\mathrm{R}^{\circledR}$ and regression analyses were represented by the Mitscherlich modified [eq. (3)]:

$$
\gamma=\gamma_{d w}-a\left(1-10^{-c x}\right)
$$

Where:

$$
\begin{aligned}
& \gamma=\text { surface tension in } \mathrm{mN} \mathrm{m}^{-1} ; \\
& \gamma_{d w}=\text { deionized water surface tension }\left(71.7 \mathrm{mN} \mathrm{m}^{-1}\right) \\
& a=\text { maximum horizontal asymptote attainable in } \\
& \text { the original model; }
\end{aligned}
$$

$c=$ curve inflection representing the efficiency of the surfactant. The higher the value of this parameter represents the most effective the surfactant is to attain the minimum surface tension in a lower concentration;

$x=$ surfactant concentration $\left(\% \mathrm{v} \mathrm{v}^{-1}\right)$,

$\gamma_{d w}-a=$ corresponds to the minimum surface tension reached by adding surfactant in aqueous solution. The Mitscherlich model was modified to achieve a better fit to the data (Silva et al., 2006), expressing the relationship between surfactant input and surface tension reduction.

For the spray retention data, a one-way analysis of variance was carried out and the significant differences compared using the Scott-Knott test $(\mathrm{P}<0.05)$. The Pearson correlation test was applied in order to elucidate the degree of linear association between SST and adjuvant concentration (AC), SST and foliar retention, and finally, $\mathrm{AC}$ and foliar retention.

\section{RESULTS AND DISCUSSION}

\section{Effect of adjuvant concentration on static surface tension reduction}

The influence of agricultural adjuvants and concentration on SST reduction provided by an adjusted modified Mitscherlich model is represented in Figure 1. Since SST remains constant at concentrations up to $0.3 \%$ of all adjuvants assessed, the SST up this point was not shown in order to provide better visualization of the SST response in lower AC. AC had a marked effect on the rate in lowering SST (Figure 1). SST decreases as concentration increases until reaching the critical micelle concentration (CMC) seen in Figure 1 (PPC adjuvant) by the inflection curve point $(c$ parameter), and thereafter, there was no change in SST values as concentration increases. 


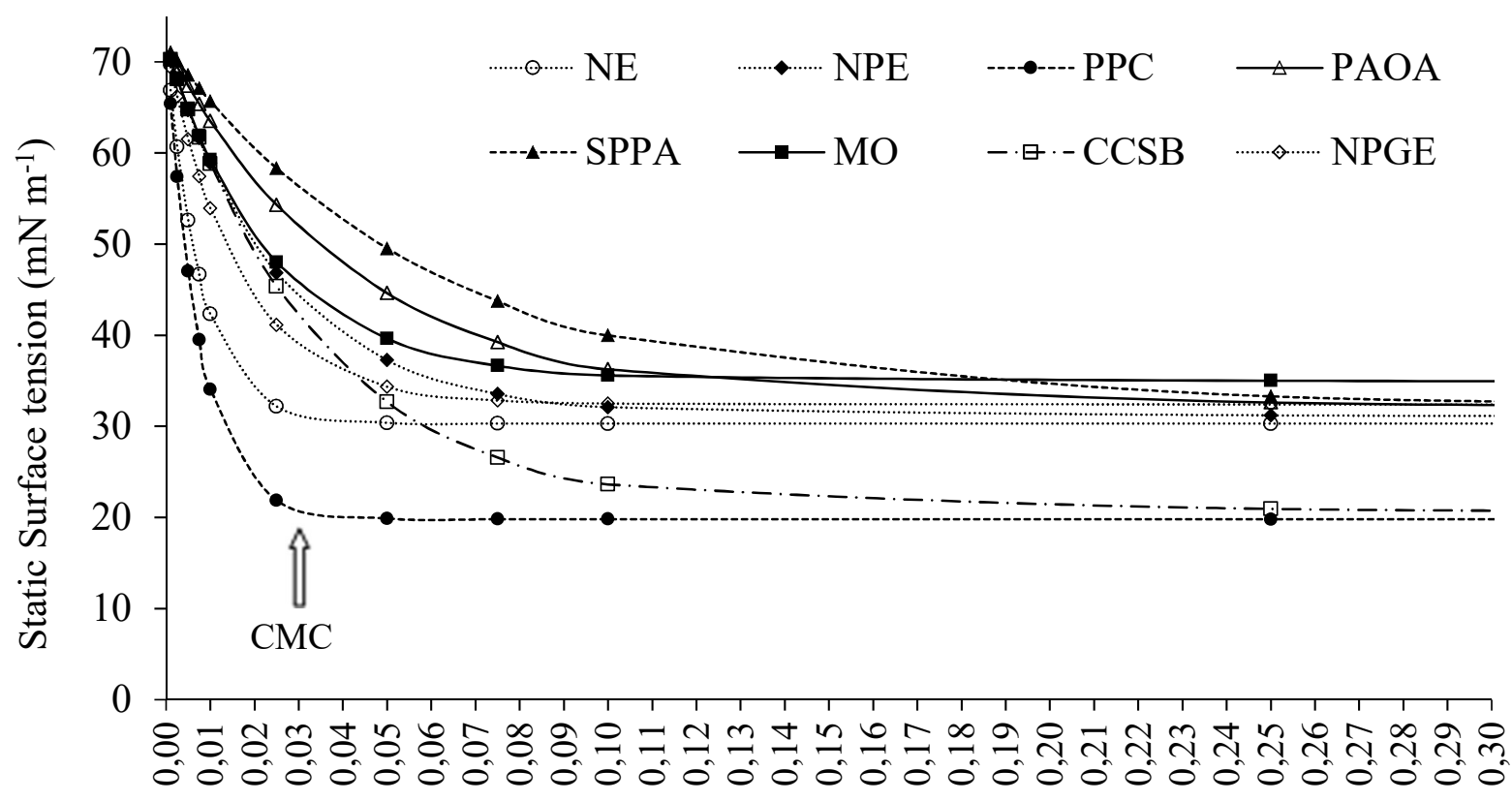

Adjuvant Concentration ( $\left.\mathrm{v} \mathrm{v}^{-1} \%\right)$

FIGURE 1. Influence of agricultural adjuvants and concentrations on reduction of static surface tension, adjusted by the modified Mitscherlich model. CMC: Critical micelle concentration.

NE: nonylphenol ethoxylate (NE); NPE: nonylphenoxy polyethoxy ethanol; PPC: polyether-polymethylsiloxane-copolymer; PAOA: primary aliphatic oxyalkylated alcohol + carboxyl; SPPA: soyal phospholipids and propionic acid; MO: mineral oil/ CCSB: carboxyl copolymer of styrene and butadiene; NPGE: nonyl polyethylene glycol ether.

Variance analysis results of SST obtained by the modified Mitscherlich model are presented in Table 2. High adjusted coefficient of determination $\left(\mathrm{R}^{2}\right.$ adj) values and significances $(\mathrm{p}<0.01)$ indicate that these equations provide good model profiles and accurate estimates of aqueous solution SST determination.

TABLE 2. Parameters of regression analysis obtained by the modified Mitscherlich model equation $\gamma=\gamma_{d w}-a\left(1-10^{-c x}\right)$ to the adjuvants.

\begin{tabular}{ccccccc}
\hline Adjuvants & $A$ & $c$ & $\begin{array}{c}\mathrm{MST} \\
\left(\gamma_{d w}-a\right)\end{array}$ & $\begin{array}{c}\mathrm{MAC} \\
\mathrm{V} \mathrm{v}^{-1}\end{array}$ & $\mathrm{~F}_{\text {regression }}$ & $\mathrm{R}^{2}{ }_{\text {adj }}$ \\
\hline polyether-polymethylsiloxane-copolymer & 51.9 & 56.1 & 19.8 & 0.05 & $26130.7^{* *}$ & 0.98 \\
\hline nonylphenol ethoxylate & 41.4 & 53.7 & 30.3 & 0.06 & $6409.8^{* *}$ & 0.81 \\
\hline nonyl polyethylene glycol ether & 39.3 & 26.1 & 32.4 & 0.11 & $15547.0^{* *}$ & 0.92 \\
\hline mineral oil & 36.7 & 18.0 & 35.0 & 0.16 & $28470.4^{* *}$ & 0.95 \\
\hline nonylphenoxy polyethoxy ethanol & 40.5 & 16.5 & 31.2 & 0.18 & $72909.4^{* *}$ & 0.99 \\
\hline carboxyl copolymer of styrene and butadiene & 50.8 & 12.7 & 20.9 & 0.24 & $36709.1^{* *}$ & 0.99 \\
\hline primary aliphatic oxyalkylated alcohol and \\
carboxyl copolymer of styrene and butadiene
\end{tabular}

${ }^{* *}$ Significantly $(\mathrm{p}<0.01)$ by Fisher' test; $\mathrm{R}^{2}$ adj: Coefficient of determination adjusted; MST: Minimum surface tension $\left(\mathrm{mN} \mathrm{m}^{-1}\right)$; MAC: Minimum adjuvant concentration to reach $\mathrm{CMC}$.

The SST reduction intensities varied with the chemical characteristics and concentrations of each adjuvant. PPC was the most efficient adjuvant in reducing the SST of deionized water. The activity of PPC in lowering SST is higher, reaching the curve point of inflection (CMC) in advance compared to the other adjuvants evaluated in this research (Figure 1). PPC reached a minimum SST value of $19.8 \mathrm{mN} \mathrm{m}^{-1}$ at a concentration of $0.05 \mathrm{v} \mathrm{v}^{-1}$ with a higher " $c$ " parameter of 56.1 (Table 2).
As with PPC, the CCSB adjuvant shows higher efficacy to reduce SST reaching a MST value of $20.9 \mathrm{~m} \mathrm{~N}$ $\mathrm{m}^{-1}$. Although the adjuvant CCSB provides higher efficiency in lowering the SST of deionized water, the MST was reached at a concentration of $0.237 \mathrm{v} \mathrm{v}^{-1}$, which is approximately 4.4 fold the MST of PPC. The adjuvants PPC and CCSB, as previously noted, were the most efficient adjuvants in reducing SST. The difference between these two adjuvants is that PPC shows higher efficiency reaching the MST in a low concentration compared to CCSB. This result is supported by the low " $c$ " 
parameter of CCSB (12.7) compared to PPC (56.1) (Table 2). The low SST reached by the CCSB adjuvant is probably attributed to the presence of a silicone fluid in the formulation.

The NE adjuvant presented a higher " $c$ " parameter value of 53.7 and showed higher efficiency in reducing SST in a low concentration, reaching the MST at a concentration of $0.06 \mathrm{v} \mathrm{v}^{-1}$. Although the NE adjuvant shows a higher " $c$ " value, the MST reached by NE was $30.3 \mathrm{mN} \mathrm{m}^{-1}$, this value is 10.5 and $9.4 \mathrm{mN} \mathrm{m}^{-1}$ above the MST from that found by PPC and CCSB, respectively (Table 2 and Figure 1).

The NPE, NPGE, PAOA, SPPA, and MO adjuvants reached similar results of MST with values of 31.2, 32.4, $32.5,32.7$, and $35.0 \mathrm{mN} \mathrm{m}^{-1}$, respectively. Although these adjuvants showed similar results of MST, distinct values of efficiency measured by the " $c$ " parameter were verified. Comparing these five adjuvants as mentioned above, higher efficiency was found for the adjuvant NPGE with "c" parameter values of 26.1 followed by NPE 16.5, MO 18.0, PAOA 10.2, and SPPA 7.3 (Table 2). MO was the adjuvant that minimally reduced SST, reaching a MST of $35.0 \mathrm{mN} \mathrm{m}^{-1}$.

The PPC, MO, CCSB, and SPPA adjuvants reached the MST in a concentration equal or lower than the label recommended concentration, while the NE, NPGE, NPE, and PAOA adjuvants reached the MST in concentrations greater than that recommend by the manufacturer's label (Table 2 and Figure 1). As expected, increasing $\mathrm{AC}$ in deionized water provided a significant reduction in SST in different intensities, depending of the adjuvant type and concentration.

Prado et al. (2016) reported the greatest capacity of super-spreader organosilicon surfactants such as PPC to reduce SST of aqueous solutions compared to the other categories of surfactants, reaching values of SST close to $20 \mathrm{mN} \mathrm{m}^{-1}$, corroborating the results found in this research. The greater efficiency of organosilicon surfactant to reduce SST is due the low cohesive energy and flexibility of siloxane moiety, which enables amphiphilic molecules to adopt proper conformation at the interface of air/water and solids (Kunieda et al., 1998).

The knowledge of how adjuvants may modify the physic-chemical properties of water, especially SST, is fundamental since water is the main vehicle to apply pesticides in foliar spray. Understanding the intensity of SST reduction by tank mix adjuvant is an important task in the pesticide application process, as droplet spread is greatly influenced by this phenomenon (Holloway et al., 2000; Lin et al., 2016).

Reducing SST of pesticide solutions could greatly improve coverage area on target surfaces (Xu et al., 2010) and may consequently increase the performance of some pesticides. The presence of adjuvants in a spray mixture may affect pesticide deposit on the leaf surface, the transcuticular diffusion of pesticides, and effect the permeability of the plasma membrane (Wang \& Liu, 2007), and may also contribute to a better retention and spread of spray solution on foliage (Gitsopoulos et al., 2014).

\section{Spray retention study}

The influence of adjuvants on coffee leaves' spray retention at different concentrations are shown in Table 3. A higher influence of $\mathrm{AC}$ on spray retention was observed on adaxial and abaxial surfaces of coffee leaves $(F=48.9$; $\mathrm{P}<0.001 ; \mathrm{n}=480$ ). In general, spray retention values decreased as AC increased, becoming constant for most adjuvants and leaf surfaces at a concentration of $0.1 \% \mathrm{v} \mathrm{v}^{-1}$.

TABLE 3. Spray retention $\left(\mathrm{mL} \mathrm{m}^{-2}\right)$ of eight adjuvant solutions at different concentrations on the adaxial and abaxial surfaces of coffee leaves. Standard deviations are presented in parenthesis.

\begin{tabular}{|c|c|c|c|c|c|c|c|c|}
\hline \multirow{2}{*}{$\mathrm{AC}(\%)$} & \multicolumn{2}{|c|}{$\mathrm{NE}$} & \multicolumn{2}{|c|}{ NPE } & \multicolumn{2}{|c|}{ PPC } & \multicolumn{2}{|c|}{ PAOA } \\
\hline & $\mathrm{Ab}-\mathrm{S}$ & Ad-S & $\mathrm{Ab}-\mathrm{S}$ & Ad-S & $\mathrm{Ab}-\mathrm{S}$ & Ad-S & $\mathrm{Ab}-\mathrm{S}$ & Ad-S \\
\hline 0 & $68.7(11.4)^{\mathrm{f}}$ & $69.2(6.1)^{\mathrm{f}}$ & $68.7(11.4)^{\mathrm{f}}$ & $69.2(6.1)^{\mathrm{f}}$ & $68.7(11.4)^{\mathrm{f}}$ & $69.2(6.1)^{\mathrm{f}}$ & $68.7(11.4)^{\mathrm{f}}$ & $69.2(6.1)^{f}$ \\
\hline 0.01 & $62.8(5.4)^{\mathrm{f}}$ & $40.3(8.8)^{\mathrm{c}}$ & $57.1(9.0)^{\mathrm{e}}$ & $53.6(5.0)^{\mathrm{e}}$ & $36.3(5.1)^{\mathrm{c}}$ & $38.2(4.3)^{\mathrm{c}}$ & $61.1(7.0)^{\mathrm{f}}$ & $63.1(8.7)^{\mathrm{f}}$ \\
\hline 0.1 & $27.4(4.1)^{\mathrm{b}}$ & $20.3(1.6)^{\mathrm{a}}$ & $30.4(6.0)^{b}$ & $29.7(2.6)^{b}$ & $25.6(3.2)^{\mathrm{b}}$ & $31.1(4.3)^{\mathrm{b}}$ & $48.8(4.6)^{\mathrm{e}}$ & $43.6(5.4)^{\mathrm{d}}$ \\
\hline 0.5 & $25.8(3.1)^{\mathrm{b}}$ & $24.7(4.5)^{\mathrm{a}}$ & $25.9(2.6)^{\mathrm{b}}$ & $29.5(4.4)^{\mathrm{b}}$ & $27.6(3.2)^{\mathrm{b}}$ & $28.0(1.1)^{\mathrm{b}}$ & $33.1(5.0)^{\mathrm{b}}$ & $28.8(4.2)^{\mathrm{b}}$ \\
\hline \multirow[t]{2}{*}{1} & $24.3(1.8)^{\mathrm{a}}$ & $21.1(2.4)^{\mathrm{a}}$ & $23.6(2.0)^{\mathrm{a}}$ & $27.9(5.0)^{\mathrm{b}}$ & $26.5(2.6)^{\mathrm{b}}$ & $27.9(3.4)^{\mathrm{b}}$ & $30.7(3.3)^{\mathrm{b}}$ & $30.0(4.2)^{\mathrm{b}}$ \\
\hline & \multicolumn{2}{|c|}{ NPGE } & \multicolumn{2}{|c|}{ SPPA } & \multicolumn{2}{|c|}{$\mathrm{MO}$} & \multicolumn{2}{|c|}{$\mathrm{CCSB}$} \\
\hline 0 & $68.7(11.4)^{\mathrm{f}}$ & $69.2(6.1)^{\mathrm{f}}$ & $68.7(11.4)^{\mathrm{f}}$ & $69.2(6.1)^{\mathrm{f}}$ & $68.7(11.4)^{\mathrm{f}}$ & $69.2(6.1)^{\mathrm{f}}$ & $68.7(11.4)^{\mathrm{f}}$ & $69.2(6.1)^{f}$ \\
\hline 0.01 & $68.4(7.9)^{\mathrm{f}}$ & $50.4(7.0)^{\mathrm{e}}$ & $41.6(6.2)^{\mathrm{d}}$ & $46.4(12.5)^{\mathrm{d}}$ & $63.2(9.3)^{\mathrm{f}}$ & $49.6(8.7)^{\mathrm{e}}$ & $69.1(13.3)^{\mathrm{f}}$ & $63.9(12.4)^{\mathrm{f}}$ \\
\hline 0.1 & $30.6(3.6)^{b}$ & $32.0(3.4)^{\mathrm{b}}$ & $28.5(6.1)^{\mathrm{b}}$ & $29.6(8.5)^{b}$ & $29.4(4.9)^{\mathrm{b}}$ & $26.2(3.5)^{b}$ & $29.2(3.4)^{b}$ & $31.7(4.9)^{\mathrm{b}}$ \\
\hline 0.5 & $26.6(4.9)^{\mathrm{b}}$ & $29.7(1.4)^{\mathrm{b}}$ & $19.7(6.4)^{\mathrm{a}}$ & $30.7(9.9)^{\mathrm{b}}$ & $27.7(5.2)^{\mathrm{b}}$ & $28.6(3.7)^{b}$ & $17.1(2.4)^{\mathrm{a}}$ & $22.5(2.0)^{\mathrm{a}}$ \\
\hline 1 & $21.0(6.1)^{\mathrm{a}}$ & $31.5(3.9)^{b}$ & $20.7(5.7)^{\mathrm{a}}$ & $30.3(2.2)^{\mathrm{b}}$ & $32.4(3.6)^{b}$ & $24.5(3.6)^{\mathrm{a}}$ & $18.2(2.2)^{\mathrm{a}}$ & $22.9(1.7)^{\mathrm{a}}$ \\
\hline
\end{tabular}

AC (\%): adjuvant concentration; Ab-S: abaxial surface; Ad-S: adaxial surface.

Different superscript letters indicate significance difference according to Scott-Knott test $(\mathrm{P}<0.05)$.

NE: nonylphenol ethoxylate (NE); NPE: nonylphenoxy polyethoxy ethanol; PPC: polyether-polymethylsiloxane-copolymer; PAOA: primary aliphatic oxyalkylated alcohol + carboxyl; SPPA: soyal phospholypids and propionic acid; MO: mineral oil; CCSB: carboxyl copolymer of styrene and butadiene; NPGE: nonyl polyethylene glycol ether. 
Spray retention on the adaxial surface did not significantly differ from retention on the abaxial surface of coffee leaves when spraying was done with water only, i.e., without adjuvant. In general, for the majority of AC, no significant differences were found between adaxial and abaxial surfaces. This result is probably explained by the similar morphological characteristics of abaxial and adaxial leaf surfaces, although these parameters were not investigated in this research.

The adjuvant PPC, at a concentration of $0.01 \% \mathrm{v}$ $\mathrm{V}^{-1}$, showed the lowest values of spray retention on both coffee leaf surfaces, differing significantly from the other adjuvants at this concentration except adjuvant NE on the adaxial leaf surface. The lower spray retention values of PPC at a concentration of $0.01 \%$ may be explained by the lower SST reached by this adjuvant at this concentration (Figure 1).

At a concentration of $0.1 \% \mathrm{v} \mathrm{v}^{-1}$, all adjuvants provided significantly lower values of spray retention on both leaf surfaces compared to spraying without adjuvant. At a concentration of $0.1 \%$, the adjuvant PAOA (Grip) provided the greater and NE (Adesil) the lesser spray retention values compared to the other adjuvants at this concentration (Table 3). The spray retention value difference between these two adjuvants is probably attributed to other characteristics, which are not necessarily caused by differences in SST. For example, the adjuvants PPC and CCSB, at a concentration of $0.1 \%$, provided lower values of SST and not necessarily the lower values of spray retention.

In general, the reduction of spray retention was more evident when the $\mathrm{AC}$ was above $0.1 \% \mathrm{v} \mathrm{v}^{-1}$, decreasing sharply from a concentration of $0.01 \%$ to $0.1 \% \mathrm{v} \mathrm{v}^{-1}$. At a concentration up to $0.1 \% \mathrm{~V} \mathrm{v}^{-1}$, the spray retention declined slowly or did not decline for most adjuvants.

Moderately negative Pearson correlations between $\mathrm{AC}$ vs SST $(\mathrm{r}=0.65 ; \mathrm{p}<0.001 ; \mathrm{n}=112)$ and AC vs spray retention $(\mathrm{r}=0.62 ; \mathrm{p}<0.001 ; \mathrm{n}=112)$ were found. Increasingly, AC provided a sharp reduction of SST and spray retention, becoming stable at a concentration of $0.3 \% \mathrm{~V} \mathrm{v}^{-1}$ (date not shown). A very strong positive correlation between SST and spray retention $(r=0.90 ; p<$ $0.001 ; n=112$ ) was verified. Gaskin et al. (2000) reported lower spray deposition on easy-to-wet leaves when the spraying was performed with an adjuvant in the spray solution. The author attributed this effect to observable spray droplet coalescence and run-off, especially when applying a higher spray volume.

The average of spray deionized water retention $\left(69.0 \mathrm{~mL} \mathrm{~m}^{-2}\right)$ was approximately 2.4 -fold greater than the average of all adjuvants on both leaf surfaces at a concentration of $0.1 \% \mathrm{v} \mathrm{v}^{-1}\left(30.8 \mathrm{~mL} \mathrm{~m}^{-2}\right)$. As SST of spray solution was decreased by the addition of an adjuvant, a reduction of spray retention was observed. The lower spray retention on coffee leaves is due to the higher spray volume used in this research (until run-off point) and the lower SST of spray solutions. Silva et al. (2008) reported a reduction of $64 \%$ on coffee leaf spray retention when spraying was realized until run-off point, in the presence of polyoxyethylene alkyl phenol ether surfactant at a concentration of $0.1 \% \mathrm{v} \mathrm{v}^{-1}$.
The lower values of spray retention with lower SST solutions may be explained by the follow steps: (1) adding surfactant in deionized water provided a SST reduction of spray solution (Figure 1); (2) the lower SST provided a lower contact angle between the droplets and leaf surface (Melo et al., 2019) increasing the wetted leaf area (Lin et al., 2016; and (3) due the greater droplet spreading area, the coalescence between the droplets increased the wetted area on the leaf surface (Xu et al., 2010) with a low quantity of solution and consequently, provided a run-off (Prado et al., 2016).

The influence of aqueous solutions with surfactants in reducing spray retention on coffee leaves sprayed until run-off point was clear. Since many foliar pesticides spray applications are necessary in this crop in order to control insects, mites, and diseases, attention should be taken that despite the use of adjuvants in the pesticide tank mix, that excessive run-off may provide inefficient control, especially in pesticides registered on a dose per volume basis. The losses by run-off using adjuvant that reduce SST in a tank mix may be accentuated during the morning time due to leaves being wetted by dew formation.

Therefore, application techniques with high volume rates in the presence of adjuvant should be avoided, especially for easily wetted leaf surfaces, since run-off can be reached more quickly and increases the losses to the environment.

Another undesirable parameter provided by excessive run-off is the risk of contamination of the soil water and air by pesticides (Pose-Juan et al., 2015). The amount of pesticide that reaches the soil may cause detrimental effects on soil microorganisms and modify the ecosystem (Cai et al., 2016). In this way, the most assertive application techniques of pesticides may reduce environmental problems and consequently, increase the performance of treatments.

Depending of the adjuvant type and concentration, the spray retention on coffee leaves was three times lower compared with the water retention without adjuvant. Caution must be taken to avoid losses by run-off when applying pesticides to coffee plants in an excessive spray volume using a tank mix adjuvant. On the other hand, the use of adjuvant/surfactant that reduces SST may be an important tool in reduced spray volume application programs in coffee crops.

\section{CONCLUSIONS}

The SST of aqueous solutions decreased as AC adjuvant concentration increased until reaching a $\mathrm{CMC}$, which varied according to each adjuvant. As expected, PPC adjuvant reached the lower values of SST in a low concentration.

The reduction of spray retention on coffee leaves was verified when an adjuvant was added in an aqueous spray solution until reaching the run-off point. The SST makes an important contribution to coffee leaves' spray retention.

\section{ACKNOWLEDGMENTS}

Research Support (Prope) of São Paulo State University, which provided a grant to the first author and infrastructure for the development of this research. 


\section{REFERENCES}

Alves GS, Cunha JPAR (2014) Field data and prediction models of pesticide spray drift on coffee crop. Pesquisa Agropecuária Brasileira 49:622-629.

Behring JL, Lucas M, Machado C, Barcellos IO (2004) Adaptação no método do peso da gota para determinação da tensão superficial: um método simplificado para a quantificação da CMC de surfactantes no ensino da química. Química Nova 27:492-495.

Cai Z, Rong Y, Chen J, Wang J, Ma J, Zhang W, Zhao X (2016) Effects of the novel cis-nitromethylene neonicotinoid insecticide Paichongding on enzyme activities and microorganisms in yellow loam and Huangshi soils. Environmental Science and Pollution Research 23:7786-7793.

Carvalho FK, Antuniassi UR, Chechetto RG, Mota AAB, Jesus MG, Carvalho LR (2017) Viscosity, surface tension and droplet size of sprays of different formulations of insecticides and fungicides. Crop Protection 101:19-23.

Costa NV, Rodrigues LFOS, Jandrey PE, Fachin GM, Glier CADS, Noreto LM (2015) Efeito de adjuvantes em soluções com fungicida na tensão superficial e na área de molhamento de gotas depositadas nas faces foliares da soja. Scientia Agraria Paranaensis 14:320-325.

Decaro Junior ST, Ferreira MDC, Lasmar O, Fouquet G (2015) Reducing spray volume for the control of Leucoptera coffeella (Lepidoptera: Lyonetiidae) in coffee plants. Coffee Science 10:491-498.

Decaro Junior ST, Ferreira MDC, Lasmar O, Campos HBN (2014) Relationship among variables of sprays applied at reduced volumes in a coffee plantation. Aspects of Applied Biology 122:415-422.

Dorr GJ, Forster WA, Mayo LC, McCue SW, Kempthorne DM, Hanan J, Zabkiewicz JA (2016) Spray retention on whole plants: modelling, simulations and experiments. Crop Protection 88;118-130.

Dorr GJ, Kempthorne DM, Mayo LC, Forster WA, Zabkiewicz JA, McCue SW, Hanan J (2014) Towards a model of spray-canopy interactions: interception, shatter, bounce and retention of droplets on horizontal leaves. Ecological Modelling 290:94-101.

Gaskin RE, Murray RJ, Krishna H, Carpenter A (2000) Effect of adjuvants on the retention of insecticide spray on cucumber and pea foliage. New Zealand Plant Protection 53:355-359.

Gimenes MJ, Zhu H, Raetano CG, Oliveira RB (2013) Dispersion and evaporation of droplets amended with adjuvants on soybeans. Crop Protection 44:84-90.

Gitsopoulos TK, Damalas CA, Georgoulas I (2014) Improving diquat efficacy on grasses by adding adjuvants to the spray solution before use. Planta Daninha 32:355-360.

Holloway PJ, Ellis MB, Webb DA, Western NM, Tuck CR, Hayes AL, Miller PCH (2000) Effects of some agricultural tank-mix adjuvants on the deposition efficiency of aqueous sprays on foliage. Crop Protection 19:27-37.

Kunieda H, Taoka H, Iwanaga T, Harashima A (1998) Phase behavior of polyoxyethylene trisiloxane surfactant in water and water-oil. Langmuir 14:5113-5120.
Lin H, Zhou H, Xu L, Zhu H, Huang H (2016) Effect of surfactant concentration on the spreading properties of pesticide droplets on Eucalyptus leaves. Biosystems Engineering 143:42-49.

Mahmood I, Imadi SR, Shazadi K, Gul A, Hakeem KR (2016) Effects of pesticides on environment. In: Khalid RH, Akhtar MS, Abdullah SNK. Plant, soil and microbes. Springer, p 253-269.

Melo AA, Hunsche M, Guedes JV, Hahn L, Feltrin NM (2019) Study of the effects of adjuvants associated with insecticides on the physicochemical properties of the spray solution and characterization of deposits on wheat and maize leaves under simulated rain. Engenharia Agrícola 39:315-322.

Pinto LFG, Gardner T, McDermott CL, Ayub KOL (2014) Group certification supports an increase in the diversity of sustainable agriculture network-rainforest alliance certified coffee producers in Brazil. Ecological Economics 107:59-64.

Pose-Juan E, Sánchez-Martín MJ, Andrades MS, RodríguezCruz MS, Herrero-Hernández E (2015) Pesticide residues in vineyard soils from Spain: spatial and temporal distributions. Science of the Total Environment 514:351-358.

Prado EP, Raetano CG, Pogetto MHF dal, Chechetto RG, Ferreira Filho PJ, Magalhães AC, Miasaki CT (2016) Effects of agricultural spray adjuvants in surface tension reduction and spray retention on eucalyptus leaves. African Journal of Agricultural Research 11:3959-3965.

Santinato F, Ruas RAA, Silva CDD, Silva RPD, Gonçalves VAR, Souza Júnior JMD (2017) Deposição da calda de pulverização em diferentes estádios vegetativos de Coffea arabica L. Coffee Science 12:69-73.

Santos HG, Jacomine PKT, Anjos LHC, Oliveira VA, Lumbreras JF, Coelho MR, Almeida JA; Araujo Filho JC, Oliveira JB, Cunha TJF (2018) Sistema de classificação de solos. Rio de Janeiro, Embrapa Solos, 5 ed.

Sasaki RS, Teixeira MM, Santiago H, Madureira RP, Maciel CFS, Fernandes HC (2015) Adjuvantes nas propriedades físicas da calda, espectro e eficiência de eletrificação das gotas utilizando a pulverização eletrostática. Ciência Rural 45:274-279.

Silva AR, Leite MT, Ferreira MDC (2008) Estimativa da área foliar e capacidade de retenção de calda fitossanitária em cafeeiro. Bioscience Journal 24:66-73.

Silva FML, Velini ED, Corrêa TM (2006) Influência dos íons $\mathrm{Mg}, \mathrm{Ca}, \mathrm{Fe}, \mathrm{Cu}$ e $\mathrm{Zn}$ sobre a tensão superficial estática de soluções contendo surfactante. Planta Daninha 24:589-595.

Wang CJ, Liu ZQ (2007) Foliar uptake of pesticides-present status and future challenge. Pesticide Biochemistry and Physiology 87:1-8.

Xu L, Zhu H, Ozkan HE, Thistle HW (2010) Evaporation rate and development of wetted area of water droplets with and without surfactant at different locations on waxy leaf surfaces. Biosystems Engineering 106:58-67.

Zhu Y, Gao Y, Zhang C, Zhao X, Ma Y, Du F (2018) Static and dynamic wetting behavior of TX-100 solution on superhydrophobic rice (Oryza sativa L.) leaf surfaces. Colloids and Surfaces A: Physicochemical and Engineering Aspects 547:148-156.

Zwertvaegher IK, Verhaeghe M, Brusselman E, Verboven P, Lebeau F, Massinon M, Nuyttens D (2014) The impact and retention of spray droplets on a horizontal hydrophobic surface. Biosystems Engineering 126:82-91. 